\title{
Study of Agroindustry Development of Sugar Cane As Efforts to Achieve Self-Sufficiency of Sugar
}

\author{
Duwi Yunitasari ${ }^{1}$, Nanik Istiyani ${ }^{2}$,Endah Kurnia $\mathbf{L}^{3}$ \\ \{duwiyunita.feb@unej.ac.id ${ }^{1}$, istiyani.fe@gmail.com², endahkurnia78@ymail.com³ \\ ${ }^{1,2,3}$ Faculty of Economics and Business University of Jember, Jl. Kalimantan 37 Jember, 68121,Indonesia
}

\begin{abstract}
Indonesia isone of the producersas well as importers of sugar.Based on thisfact, Indonesia should pay attention on the development of sugar cane agro-industry to ensure the fulfillment of sugar demand in the country.As a matter of fact,sugar is a strategic commodity toincreasefarmers' prosperity andalsoinfavour of consumers' sensitivity to sugar pricevolatility. There fore, a thorough review of various stake holders in sugar industry to develop policies for real contribution to the national economy needs to be taken. The research deployed survey method, data collection (primary and secondary data) through field survey (observation), question naires, interview and literature study. Development strategy analysis method uses a tiered decision technique known as Analytical Hierarchy Process (AHP).The results of strategy analysis to achieve selfsufficiency of sugar with the development of sugar agro-industry showed that off-farm and institutional factors follow on farm factoron top priority to ahcieve self-sufficiency of sugar.Furthe rmore, on farm criteria have several alternatives with thepriority of land ownership, sugar cane productivity and price stability.
\end{abstract}

Keyword: Sugar cane Agro-industry, Analytical Hierarchy Process, Self-sufficiency of Sugar

\section{Introduction}

In 1930s,Indonesia was once the second largest exporter of sugar (with export volume approximately3 million tons of white crystal sugar)after Cuba worlwide(Mardianto, S., et al., 2005; Marpaung, Yanto., et al, 2010). However,from 1967 todate Indonesia has transformed to be one of great sugar importers.Yet, as a matter of fact, sugar as one of strategic commodities is highly regulated. The current profile of the sugar industry in Indonesia maintainsinefficiency; withun-integrated government policies. Sugar industry is managed by five ministries, with the presidentusestheauthority of industrial managementbut the implementation infavour of off farm ismanagedbytheMinistry of Industry. Whereas, infavour of on farm side the Ministry of Agriculturetakesthecontrol. Sugar Manufacturer which belongs to the Ministry of State-owned Enterprises (BUMN) takes sugar cane.The Ministry of Forestry providesland for sugar cane and the Ministry of Trade worksas thetraffic regulator of sugar imports including the determination of raw sugar for refineries and sugar for consumption.

The increasingly deplorable situation of the domestic sugar industry is indicated by the decline of sugar price duetoa widerange of factorssuch as low price of refined sugar crystals (GKR) compared to that of white crystal sugar (GKP), fluctuative productions, the decrease of acreage, the decrease of sugar cane productivity per hectare and the low rate of rendement, More over, the situation of current sugar industry as well as thecondition of sugar factories are increasingly inefficient.

The growing limitation of sugarcane area, the decrease of sugar cane productivity atfarm level (sugarcane plantation) due to ratoon cultivating system, inefficiency of off farm level 
duetolow quality of sugarcane raw material and poor maintainance of sugar mill sand poor management of slash-and-slope processing and that ofboth factory level and sugar cane growing area shave hinde rednational sugar production which eventually contributes significantly low productivity of sugar in Indonesia(Yunitasari, 2015). More over, theneed of sugar imports raises concerns about the future of Indonesia's sugar self-sufficiency.

Hence, sugar price in stability becomes the focus of annual agendat overcome. Further more, the targetof sugarself-sufficiency is far from reality as it iso bviously reflected bycontinually revised sugar self-sufficiency target(Arifin, B., 2008). Ironically, the government insists on self-sufficiency achieve ment throughthe production of refined sugar raiseby raw sugar import not even from domestic sugar cane. Raw sugar is currently not the subject of import duties $(0 \%)$. Thus, production targets was achieved, inflation ratewa slow but farmers will be displaced.

In theefforts of achieving sugar self-sufficiency, constraints from bothon farm and off farmare often encountered. There fore, decision support system is needed to determine which strategy to be effective inrealizing Indonesia sugar self-sufficiency based on stipulate dcriteria.It deployed decision support system application with Analytical Hierarchy Process (AHP) method for data processing to determine the peopleinchargein sugar agro-industry. Analytical Hierarchy Process (AHP) is attribute comparison which provides means for decision-making techniques developed by Thomas L. Saatyin the 1970sfor more complex decisions (Chauhan., et al., 2008; Koc and Burhan, 2015).The study aims atexploringthe strategy of sugar cane agro-industry development in realizing food self-sufficiency through sugar self-sufficiency.

\section{Method}

This is a quantitative descriptive research conducted in 2017 withtheuse of 5 respondents such as Government (Ministry of Agriculture), PT. Perkebunan Nusantara, Sugar Factory, Sugarcane Farmers, Academicians and Community Leader (Association of Small holder Sugar cane Farmers, Sugar Plantation Research Center). Panel data in the form of primary as well as secondary data were used. Primary data is a data source obtained directly from original onewhichcan be subject opinion (person) individually or in groups, object observation (physical), event or activity, and test results. Secondary data is that of obtained from books, journals and related publications.

The research used analysis tools of Analytical Hierarchy Process. The comprehensive decision-making method was firstly introduced by Thomas L. Sa at yasit concerns qualitative and quantitative steps as follows: identifying system, identifying problems, finding the solution, and creating the hierarchy structure(Aguilar., et al, 2012). 


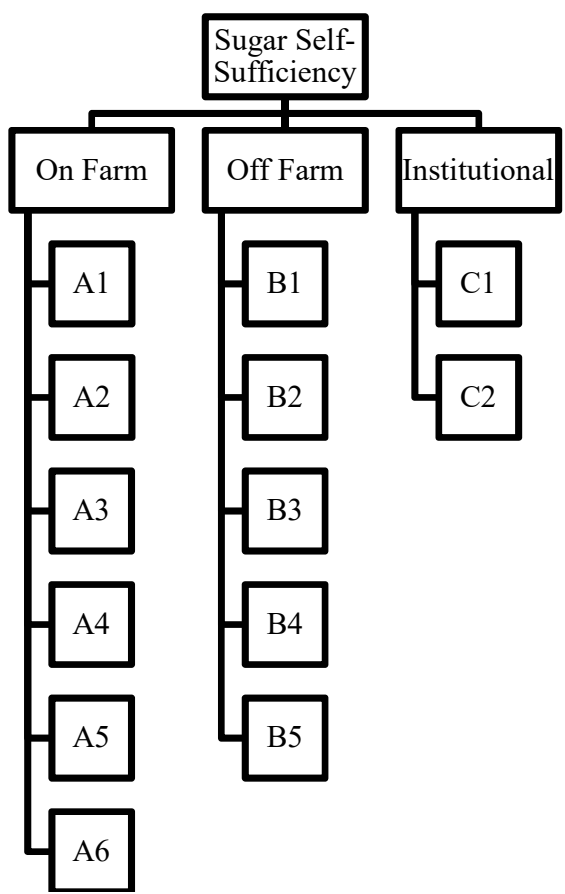

Fig.1. The AHP Hierarchyto Analyse The Development Strategy of Sugar Agro-industry in Realizing Sugar Self-sufficiency in Indonesia.

Table 1. Criteria and Sub-Criteria Strategy of Sugar Agro-industry Development in Achieving Sugar Self-Sufficiency in Indonesia.

\begin{tabular}{ll}
\hline On Farm & A1: Land Ownership \\
& A2: Cane Productivity \\
& A3: Price Certainty \\
& A4: Capital \\
& A5: Partnership \\
& A6: Government Intervention \\
\hline Off Farm & B1: Sugar Factory Management \\
& B2: Sugar Factory Productivity \\
& B3: Sugar Cane Rendimen \\
& B4: Cane Stock \\
& B5: Optimization of Milled Capacity (Milling-Hour Stop) \\
\hline Institutional & C1: Sugar Industry Policy \\
& C2: Cooperative \\
\hline
\end{tabular}

Table 2.Value Scale of Interest and theremarks for AHP Analysis.

\begin{tabular}{ll}
\hline Value & Remarks \\
\hline Value 1 & Bothfactor of the same importance \\
\hline Value 3 & One factorisless important than the other \\
\hline Value 5 & One factoris more important than the other \\
\hline Value 7 & One factoris obviously more important than the other \\
\hline
\end{tabular}




\begin{tabular}{ll}
\hline Value 9 & One factor is absolutely more important than the other \\
\hline Value 2,4,6,8 & AmongstValues, between 2 considerably close values \\
\hline
\end{tabular}

(Saaty, 1980)

\section{Finding And Argument}

The AHP analysis usesthree criteriassuch as on farm, off farm and institutional. Analytical Hierarchy Process (AHP) is sucha technique to support decision-making process aiming to determine the best option of a widerange of alternatives(Fong and Choi, 2000; Buyukyazici and Sucu, 2003; Messer and Allen, 2010; Kaya and Kahraman, 2011; Balubaid and Alamoudi, 2015; Russo and Camanho, 2015; Harbi, 2017). To reach food self-sufficiency through sugar self-sufficiency requires the development of sugarcane agro-industry.

\subsection{The Results of Criteria Analysis}

Criteria play apivotalrole in sugar self-sufficiency which is meant to bethe ability of domestic sugar production to meet the needs of direct consumption (final demand) and for the food and beverage industry (intermediate demand).There are some points to ponder dealingwith the importance of sugar self-sufficiency in Indonesia, amongothers: (1) sugar becomesthe basic needs of peoplein Indonesia and there for eits hould be always available in sufficient quantities with reasonable price range. This is part of food security aspectas it is very important due to Indonesia's huge demand for sugar;(2) sugar production can be significantly increased as sugar cane farmers are able to cultivate sugar cane even with government's support in the form of policies and adequate investment capital;(3) domestic sugar industry shows sufficient potentia land isevenable to meet national needs indicated through expansion of potential areas which eventually support the expansion of the national sugar industry.

Sugar self-sufficiency applies three primary criterianamely on farm, off farm and institutional .Based on AHP result through expert choice,out of the three criteria, on farm ha the biggest role with value (0.659), off farm, then on farmat the second place with value $(0.168)$, and last ly institutional with(0.153). Ratio inconsistency obtained is 0.06. (Padmowati, 2009)suggested that when the value of consistency ratio is less than 0.1 , the result is then consistent, as indicated in the following figure:

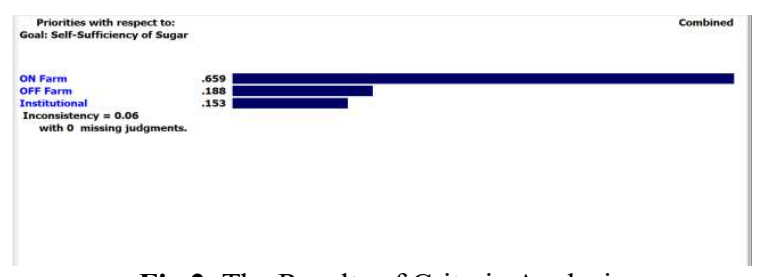

Fig.2. The Results of Criteria Analysis

Based on Figure 2. On farm has a very important role and becomes the top priority in sugar selfsufficiency. This is due to cultivation of on farmand sugar cane plant as raw material in sugar cane production, so good facilities should be well provided to improve the quality of sugar cane. Inefficiency in the sugar cane scale of the farmers stems from repeated pressure problems even up to a dozen times, because of the unavailability of rate on dismantling funds. Besides, sugar cane farming business is getting shifted by other commodities which generate higher income, such as rice, maize, crops and horticulture. It is therefore not surprising that the area of sugar cane is limited especially in the area of rice fields. the incentives of sugar cane farmers in increasing the productivity of sugar cane also needs to be considered.Off farm becomes second priority because as a supporter in increasing sugar selfsufficiency, and become support to increase sugar cane production through sugar mill performance through its productivity and the amount of its milling capacity not yet optimal soit needs to get priority in 
realizing sugar self-sufficiency. Institution becomes the last priority because institutional as a container has regulation to support increase sugar self-sufficiency, where the need of partnership between sugarcane farmers and sugar factory even in sugar industry management and policies in sugar industry in Indonesia.

\subsection{The Result of AlternativeAnalysisin On FarmCriteria}

On farm is a top priority in sugar self-sufficiency and has several alternatives to achieve the goal. The development of sugar cane agro-industry is inseparable from the contribution of sugarcane farmers where the people's sugar cane depends on the stock of sugar cane produced by farmers. The declining planting area from year to year, the decision of planting time, variety, fertilization and maintenance is entirely in the hands of many sugarcane farmers, with diverse skills and capital capabilities, so that this greatly affects the productivity of the people's sugar cane as a producer of white crystal sugar because the loss of sugar occurs a lot from cutting to grinding (post harvest losses can reach $30 \%$ both errors in time of cutting planted varieties, transportation or harvest scarcity). The presence of inefficiency in postharvest affects the decrease of sugar yield, as farmers are often constrained by additional costs so that it takes a long time. The study shows some alternatives of goals. The alternatives are land ownership, sugarcane productivity, price certainty, partnership capital and interference in the cultivation and sugar cane post harvest. Of the several alternatives, the main priority is land ownership with value $(0.264)$, then sugarcane productivity with value $(0.259)$, thenprice certainty with value $(0.190)$, capital becomes thenextpriority with value $(0.132)$, the fifth priority is partnership with value $(0.093)$, and the last is the interferencein the cultivation and sugar cane post harvest with value $(0.062)$. theratio inconsistency obtained is 0.07 as indicated in the following figure:

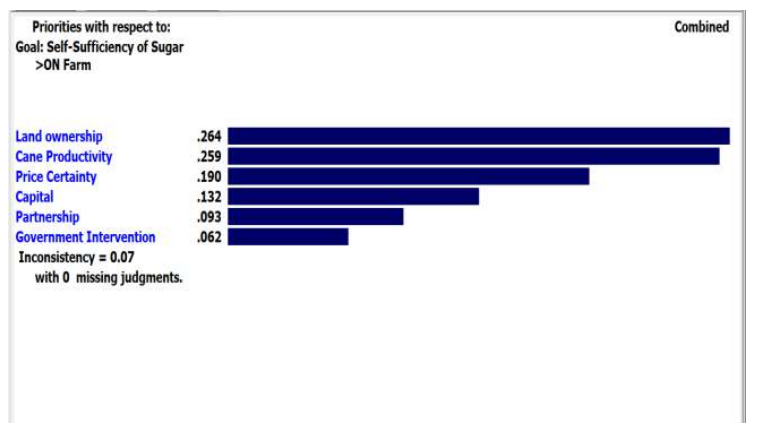

Fig.3. The Result of Alternative Analysis in On Farm Criteria.

\subsection{The Result of AlternativeAnalysisinOffFarm Criteria}

Off farm becomes the second priority in sugar self-sufficiency and has several alternatives to achieve the goal. In this case off farms include sugar mills, especially the state-owned sugar mills that often experience milled jams known as the inactive sugar factory. This is due to many sugar factories which still operate 4-5 months during harvest. The state-owned sugar industry faces no small constrains i.e.too large number of human resources involved, resulting in very high over head costs. In addition, the extent of own sugar cane (TS) owned by stateowned enterprises is only one fifth of the sugar cane field (TR), consequently sugar production is highly dependent on the willingness of farmers to plant sugar cane. Further more, in some state-owned sugar cane productions cost it self is higher than the cost of people's sugar 
cane.This causes the sugar factory dependence on farmers become seven greater. Reduced supply of sugar cane to the mill will increase the milling hours which means increased fuel costs and will eventually increase production costs. In contrast to private sugar factories which own large areas of land, both from cultivation right sand leasing, it can integrate farm management with processing. cropping, hauling and milling schedule can be arranged perfectly and yield can be estimated more precisely. The alternatives are sugar mill management, sugar mill productivity, sugar cane yield, sugarcane stock, milling capacity optimization. Of the several alternatives, the main priority is the management of sugar mills with value (0.333), the second is the productivity of the sugar factory with the value $(0.301)$, the third is sugar cane rendemen with value (0.179), sugarcane stock becomes the fourth priority with value $(0.101)$, then the optimization of rolling capacity (milling hours) with value (0.086). The ratio of inconsistency is 0.08 .

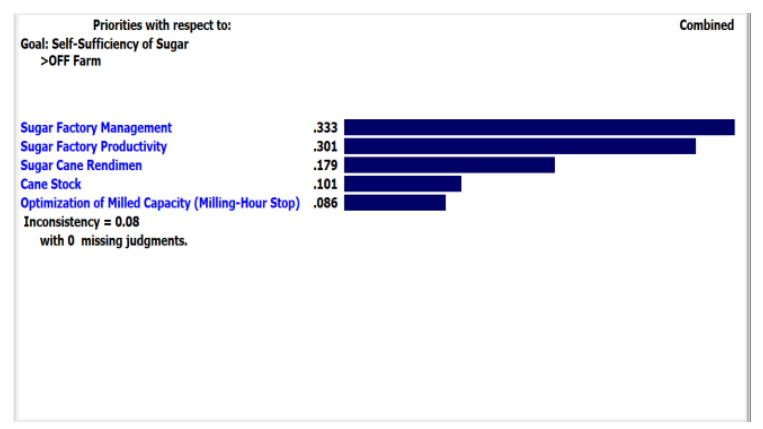

Fig.4. The Result of Alternative Analysis in Off Farm Criteria.

\subsection{TheResult of AlternativeAnalysisinInstitutionalCriteria}

Institutional becomes the last priority in sugar self-sufficiency and has two alternatives to achieve thegoal. The cheap price of sugar does not reflect the efficiency of production, but duetoa distorted policy on the international market. The low sugar price is the result of many factors, among whicharerefined sugar entry to be imported only for the food and beverage industry.In fact, seeping into white sugar consumers (refined sugar prices are much cheaper than white crystal sugar), production fluctuations, the decrease of area, the decrease of sugar cane productivity and low rendamen level. This clarifies that the current profile of the sugar industry remains in efficient which is indicated by un-integrated government policy as managedby five ministries. Thus, rearrangement of national sugar policy needs to be reconsidered to ensure one-door policies, including the recommendation of importing various types of sugar. Due to the absence of sanctions for abusive companies, refined sugar mills produce refined sugar with quantities and qualities in accordance with the needs of food, beverage and pharmaceutical industries, in order that refined sugar production does not absorptin the market of White Crystal Sugar.

In addition, the tariff increases several times from the current level as long as it does not violate the WTO agreement, due to low tariffin Indonesia. The condition of farmers is less secure in the production of sugar cane as the stock of sugar production, due to unfavorable regulation. Likewise with the less well-off Cooperative, the majority of sugar cane cooperatives in East Java are in diseconomies of scale, indicating that the cooperatives operate inefficiently. The following factors are: (1) the cooperative runs its business with small scale farmers, causing high administrative and monitoring costs; (2) weak risk management and low 
profit levels; (3) inefficient management; and (4) bureaucracy, high wages, and inefficient operations. The alternative is the policy of importedsugar and cooperative. Of the two alternatives, the main priority is the policy of imported sugar with value $(0.535)$ and Cooperative with value (0.465). Ratio inconsistency obtained is 0.00 .

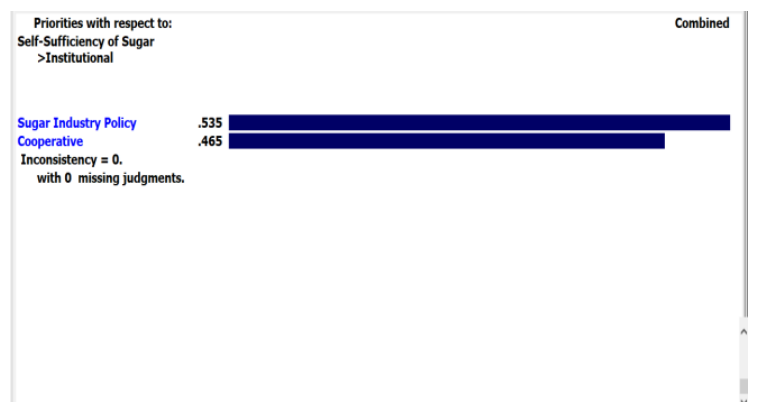

Fig.5. The Result of Alternative Analysis in Institutional Criteria.

\section{Conclusion}

Based on the analysis, wecome to the conclusion in dicatedas follows: The determination of achievement strategy of sugar self-sufficiency through development of sugar cane agroindustry in Indonesia becomes the main priority which can be seen from on farm with the value of $(0.659)$ and with some alternatives to reach the goal. What bcomes the main priority is land ownership with thevalue of (0.264), productivity of sugar cane is located on the second priority with the value of $(0.259)$, price certainty is then the next place with thevalue of (0.190). Capitalisplaced on the fourth priority with thevalue of $(0.132)$, fifth priority is landed by partnership with the value of $(0.093)$, last placeis forinterference in cultivation and post harvest of sugarcane with the value of (0.062).

\section{References}

[1] Aguilar et al, 2012 'A Methodological Approach to Sugar Mill Diversification and Conversion', Ingenieria E Investigacion, 32(2), pp. 23-27.

[2] Arifin, B, 2008 'Ekonomi Swasembada Gula Indonesia', Economic Review, (211), pp. $1-12$.

[3] Balubaid and Alamoudi 2015 'Application of the Analytical Hierarchy Process ( AHP ) to Multi-Criteria Analysis for Contractor Selection', (September), pp. 581-589.

[4] Buyukyazici and Sucu, 2003 'The Analytic Hierarchy and Analytic Network Processes', Hacettepe Journal of Mathematics and Statistics, 32, pp. 65-73.

[5] Chauhan., et al. 2008 'The Analytic Hierarchy Process as a Decision-Support System in the Housing Sector: A Case Study', World Applied Sciences Journal, 3(4), pp. 609613.

[6] Fong and Choi, 2000 'Final Contractor Selection using The Analytical Hierarchy Process', Construction Management and Economics, 18(5), pp. 547-557. doi: 10.1080/014461900407356.

[7] Harbi, 2017 'Application of the AHP in Choosing Project Manager', Ijels.Com 19, , pp. 19-27.

[8] Kaya, T. and Kahraman, C, 2011 'An integrated fuzzy AHP-ELECTRE methodology for environmental impact assessment', Expert Systems with Applications, 38(7), pp. 
8553-8562. doi: 10.1016/j.eswa.2011.01.057.

[9] Koc and Burhan, 2015 'An Application of Analytic Hierarchy Process (AHP) in a Real World Problem of Store Location Selection', Advances in Management \& Applied Economics, 5(1), pp. 41-50.

[10] Mardianto, S., et al, 2005 'Peta Jalan (Road Map) dan Kebijakan Pengembangan Industri Gula Nasional.', Forum Penelitian Agro Ekonomi, 23 No. 1, pp. 19-37.

[11] Marpaung, Yanto., et al, 2010 'Indonesian Journal of Agricultural Economics ( IJAE )', Indonesian Journal of Agricultural (IJAE), 2, pp. 97-119.

[12] Messer and Allen (2010) 'Applying Optimization and The Analytic Hierarchy Process to Enhance Agricultural Preservation Strategies in The State of Delaware', Agricultural and Resource Economics Review, 39(3), pp. 442-456. doi: $10.1017 / \mathrm{S} 1068280500007437$.

[13] Padmowati (2009) 'Pengukuran Index Konsistensi Dalam Proses Pengambilan Keputusan', Seminar Nasional Informatika, 2009(semnasIF), pp. 80-84.

[14] Russo and Camanho, 2015 'Criteria in AHP: A Systematic Review of Literature', Procedia Computer Science. Elsevier Masson SAS, 55(Itqm), pp. 1123-1132. doi: 10.1016/j.procs.2015.07.081.

[15] Saaty, 1980 'The Analytic Hierarchy Process: What It Is and How It Is Used', 9(3-5), pp. $161-176$. Available

at: http://www.sciencedirect.com/science/article/pii/0270025587904738.

[16] Yunitasari, 2015 'Model Pengembangan Agroindustri Gula Tebu Sebagai Upaya Peningkatan Perekonomian Wilayah di JawaTimur'. 